\title{
Analytical Method Development of Quantification and Dissolution Assay of Ursodeoxycholic Acid Capsule
}

\author{
Wanti Megawati ${ }^{1}$, Sophi Damayanti ${ }^{*}$ \\ ${ }^{1}$ School of Pharmacy, Institut Teknologi Bandung, West Java, Indonesia
}

\begin{abstract}
Submitted 30 December 2020; Revised 24 January 2021; Accepted 10 February 2021; Published 29 October 2021
*Corresponding author: sophi.damayanti@fa.itb.ac.id
\end{abstract}

\begin{abstract}
Ursodeoxycholic acid is an active compound to treat cholesterol gallstones and included in Biopharmaceutical Classification S ystem c lass II. Ursodeoxycholic a cid c apsule formulations have been developed by the pharmaceutical industries. Due to requirement, assay and dissolution tests need to be routinely carried out to control quality of the drug. Therefore, aim of this study was to develop a simultaneously analytical method for assay and dissolution test. Optimum condition of analysis were using HPLC-RID, $\mathrm{C}_{18}$ column $(5 \mu \mathrm{m} ; 3.9 \times 300 \mathrm{~mm})$, acetonitrile:phosphate buffer $\mathrm{pH}$ $3.0(55: 45 \mathrm{v} / \mathrm{v})$ as mobile phase with flow rate $1 \mathrm{~mL} / \mathrm{min}, 50 \mu \mathrm{L}$ injection volume, column, detector, and sample temperature were set at $40{ }^{\circ} \mathrm{C}$. This method provides good linearity in a range of 50$130 \%$ concentration for assay and dissolution test with correlation coefficient values of 1 and 0.999 . respectively. LOD and LOQ for assay were of $4.892 \mu \mathrm{g} / \mathrm{mL}$ and $14.824 \mu \mathrm{g} / \mathrm{mL}$ whereas for dissolution tests of $6.501 \mu \mathrm{g} / \mathrm{mL}$ and $19.701 \mu \mathrm{g} / \mathrm{mL}$. The average percent recovery for assay and dissolution test were in a range of $100.018 \pm 0.888 \%$ and $98.936 \pm 2.124 \%$. Repeatability and intermediate precision of assay were obtained by determining RSD values of $0.466 \%$ and $0.279-0.483 \%$, while the dissolution test were $1.137 \%$ and $0.032-0.289 \%$.
\end{abstract}

Keywords: Assay, dissolution test, Ursodeoxycholic acid, validation

\section{Pengembangan Metode Analisis Uji Kadar dan Uji Disolusi Kapsul Asam Ursodeoksikolat}

\begin{abstract}
Abstrak
Asam ursodeoksikolat merupakan senyawa aktif obat untuk mengobati batu empedu kolesterol yang termasuk dalam Biopharmaceutical Classification S ystem k elas I I. F ormulasi k apsul asam ursodeoksikolat banyak dikembangkan oleh industri farmasi sehingga pengujian bahan aktif dan uji disolusi perlu dilakukan secara rutin untuk mengontrol kualitas obat. Oleh karena itu, tujuan penelitian ini adalah pengembangan metode analitis yang dapat digunakan untuk penetapan kadar dan uji disolusi secara bersamaan. Penelitian ini menggunakan KCKT dengan detektor indeks bias, kolom $\mathrm{C}^{18}$ (5 $\mu \mathrm{m} ; 3,9 \times 300 \mathrm{~mm})$, fase gerak asetonitril:dapar fosfat $\mathrm{pH} 3,0(55: 45 \mathrm{v} / \mathrm{v})$ dengan laju alir $1 \mathrm{~mL} /$ menit, volume penyuntikan $50 \mu \mathrm{l}$, suhu kolom, detektor, dan sampel $40{ }^{\circ} \mathrm{C}$. Metode ini memberikan linearitas yang baik pada rentang konsentrasi 50-130\% untuk penetapan kadar dan uji disolusi dengan nilai koefisien k orelasi masing-masing $1 \mathrm{~d}$ an 0,999 . Batas deteksi $\mathrm{d}$ an $\mathrm{k}$ uantisasi u ntuk penetapan kadar 4,892 $\mu \mathrm{g} / \mathrm{mL}$ dan $14,824 \mu \mathrm{g} / \mathrm{mL}$, untuk uji disolusi $6,501 \mu \mathrm{g} / \mathrm{mL}$ dan $19,701 \mu \mathrm{g} / \mathrm{mL}$. Ratarata persen perolehan kembali penetapan kadar dan uji disolusi berturut-turut $100,018 \pm 0.888 \%$ dan 98,936 $\pm 2.124 \%$. Keberulangan dan presisi antara penetapan kadar diperoleh nilai RSD 0,466\% dan 0,279-0,483 \%, sedangkan uji disolusi sebesar $1,137 \%$ dan 0,032-0,289 \%.
\end{abstract}

Kata Kunci: Asam ursodeoksikolat, KCKT, penetapan kadar, uji disolusi, validasi 


\section{Introduction}

Ursodeoxycholic acid $\left(\mathrm{C}_{24} \mathrm{H}_{40} \mathrm{O}_{4}\right)$ or UDCA is an active drug compound and widely used in capsule, tablet, and liquid formulations for the treatment of cholesterol gallstones and has recently been introduced to treat cholestatic liver disease. ${ }^{1,2}$ Ursodeoxycholic acid is a class II in Biopharmaceutical Classification System (BCS) with low solubility and high permeability. ${ }^{3,4}$ Ursodeoxycholic acid is a hydrophilic bile acid found in small amounts in humans. ${ }^{5}$

Ursodeoxycholic acid capsule formulations has been developed by the pharmaceutical industries. Therefore, the development of new methods and optimization of drug analysis and validation are important tasks in pharmaceutical science. According to drug regulatory agencies, the determination of the levels of active substances in drugs and dissolution testing are important factors in controlling quality of the drugs. ${ }^{6}$

Several studies related to the analysis of ursodeoxycholicacidinformulationshavebeen reported, including using the HPLC-DAD with derivatization, ${ }^{7}$ UV-Vis spectrophotometer method with derivatization ${ }^{8}$, HPLC with a UV detector ${ }^{9}, 10,11$, and HPLC with refractive index detector. ${ }^{12}$ From previous research for analyzed of Ursodeoxycholic acid by comparative evaluation between UV detector and refractive index detector show the conventional UV detectors are less sensitive than refractive index detector to analyze compounds with low molar absorption, such as Ursodeoxycholic acid ${ }^{13}$ and UDCA shows moderate absorption only in short UV wavelength region $200-210 \mathrm{~nm}$, therefore quantification of the amount released from the pharmaceutical preparations by simple UV spectrophotometry was hampered by possible interferences from excipients in formulation and components in dissolution medium. ${ }^{14}$ Hence, refractive index detector could be selected because it is a universal detector since it monitors a bulk property of analyte and very suitable for analyzing compounds without a strong UV chromophore such as Ursodeoxycholic acid. ${ }^{15}$
From all previous studies, development and validation method was only focus for assay or only for dissolution test of Ursodeoxycholic acid in formulations. Therefore, in this study carried out the development and validation of the HPLC method analysis with a refractive index detector that can be used for assay and dissolution test of Ursodeoxycholic acid capsules simultaneously with the same chromatographic conditions system and also effective that never reported before. This method is expected to be used as a quality control in pharmaceutical company research laboratories for routine determination of Ursodeoxycholic acid capsule tests. The development assay method and dissolution test with the HPLC that used for drug determination were validated according to the International Conference on Harmonization (ICH) and the United State of Pharmacopoeia (USP).

\section{Methods}

2.1. Equipments

Analytical scales (Mettler Toledo and Sartorius), beaker glass (Pyrex), ultrasonicator bath (Branson 8800), pipettes, Whatman quantitative filter paper (Millipore), HPLC-refractive index detector (Waters 2414), filters hydrophilic $0.20 \mu \mathrm{m}$ (Agilent), spatula, volumetric flask (Iwaki), measuring cup (Pyrex), column $\mathrm{L}_{1}\left(\mathrm{C}_{18}\right) 5 \mu \mathrm{m} ; 3.9$ x 300 $\mathrm{mm}$ (Waters), $\mathrm{pH}$ meter (Mettler Toledo MP220), volumetric pipette (Iwaki), dissolution apparatus (Vission Elite G-2 Hanson), oven (Memmert), TLC Visualizer (Camag) and vacuum filter (Millipore).

\subsection{Materials}

Ursodeoxycholic acid reference standard (Sichuan Xieli), Ursodeoxycholic acid capsules (PT. Kimia Farma), $\mathrm{KOH}$ (Merck), distilled water, sodium lauryl sulfate, $\mathrm{KH}_{2} \mathrm{PO}_{4}$ grade ISO (Merck), $\mathrm{H}_{3} \mathrm{PO}_{4}$ $80 \%$ grade ACS-ISO-Reag. Ph Eur (Merck), acetonitrile HPLC grade (J.T.Baker), methanol HPLC grade (J.T.Baker), $\mathrm{NaOH}$ grade ISO (Merck), $\mathrm{HCl}$ grade ACS-ISOReag. $\mathrm{Ph}$ Eur (merck), $\mathrm{H}_{2} \mathrm{O}_{2}$ grade ISO 
(Merck) dan placebo (PT. Kimia Farma).

\subsection{Procedure}

\subsubsection{Preparation of Mobile Phase}

The mobile phase was prepared from a mixture of acetonitrile and $0.075 \mathrm{M} \mathrm{KH}_{2} \mathrm{PO}_{4}$ solution with a ratio $(55: 45 \mathrm{v} / \mathrm{v})$ and then homogenized. The $\mathrm{pH}$ of the solution was adjusted to 3.0 with the addition of phosphoric acid. Then the solution was filtered with a 0.2 $\mu \mathrm{m}$ filter.

\subsubsection{Preparation of Dissolution Medium}

Preparation of dissolution medium refers to USP $42^{\text {nd }}$ by Weighed $6.8043 \mathrm{~g}$ of $\mathrm{KH}_{2} \mathrm{PO}_{4}$ and $3.1419 \mathrm{~g}$ of $\mathrm{KOH}$ into a $1000 \mathrm{~mL}$ beaker glass, dissolved in $530 \mathrm{~mL}$ of distilled water then added with $5 \mathrm{~mL}$ of $2 \%$ Sodium Lauryl Sulfate. The $\mathrm{pH}$ of the solution is adjusted with dilute $\mathrm{KOH}$ to a $\mathrm{pH}$ of 8.4. Furthermore, the distilled water was added to $1000 \mathrm{~mL}$

\subsubsection{Preparation of Standard Solution}

Preparation of standard solution for assay refers to USP $42^{\text {nd }}$ by weighed $\pm 40 \mathrm{mg}$ of Ursodeoxycholic acid reference standard into a $10 \mathrm{~mL}$ volumetric flask. Then $5 \mathrm{~mL}$ of methanol was added, sonicated for 15 minutes, and methanol was added again until the limit mark (Solution A). Furthermore, $5 \mathrm{~mL}$ of solution A was piped into a $25 \mathrm{~mL}$ volumetric flask, dissolved in the mobile phase up to the limit mark, and homogenized (reference standard concentration: $800 \mu \mathrm{g} /$ $\mathrm{mL}$ ). Then the solution was filtered with a 0.2 $\mu \mathrm{m}$ filter.

Preparation of standard Solution for dissolution test refers to USP $42^{\text {nd }}$ by weighed $\pm 25 \mathrm{mg}$ of Ursodeoxycholic acid reference standard into a $100 \mathrm{~mL}$ volumetric flask, 5 $\mathrm{mL}$ of methanol was added and sonicated for 15 minutes. Furthermore, the dissolution medium was added to the limit mark, shaken and homogenized (reference standard concentration: $250 \mu \mathrm{g} / \mathrm{mL}$ ). Then the solution was filtered with a $0.2 \mu \mathrm{m}$ filter.

\subsubsection{Preparation of Simulation Sample}

Preparation of simulation sample for assay refers to USP $42^{\text {nd }}$ by mixed Ursodeoxycholic acid reference standard and placebo, then crushed until homogeneous. For the assay, the amount of placebo equivalent to $\pm 200 \mathrm{mg}$ of Ursodeoxycholic acid was used, then put it in a $50 \mathrm{~mL}$ volumetric flask, $40 \mathrm{~mL}$ of methanol was added and sonicated for 15 minutes, and then methanol was added back to the limit mark (Solution A). Then $5 \mathrm{~mL}$ of solution A was piped into a $25 \mathrm{~mL}$ volumetric flask, diluted with the mobile phase up to the limit mark (simulation sample concentration: $800 \mu \mathrm{g} / \mathrm{mL}$ ). Then the solution was filtered with a $0.2 \mu \mathrm{m}$ filter.

Preparation of simulation sample for dissolution test refers to USP $42^{\text {nd }}$ by mixed Ursodeoxycholic acid reference standard and placebo, then crushed until homogeneous. For the dissolution test, the amount of placebo was used equal to one capsule of Ursodeoxycholic acid $( \pm 250 \mathrm{mg})$. Then the simulation sample powder was dissolved in the medium and according to the dissolution test conditions (simulation sample concentration: $250 \mu \mathrm{g} /$ $\mathrm{mL})$. Furthermore, the filtrate test results were dissolved and filtered with a $0.2 \mu \mathrm{m}$ filter.

\subsubsection{Chromatographic conditions}

Chromatographic conditions were using Column $\mathrm{L}_{1}\left(\mathrm{C}_{18}\right) 5 \mu \mathrm{m} ; 3.9$ x $300 \mathrm{~mm}$, Flow rate $1 \mathrm{~mL} /$ minute, injection volume 50 $\mu \mathrm{L}$, column, detector, and sample temperature was maintained at $40{ }^{\circ} \mathrm{C}$. While dissolution test condition refers to USP $42^{\text {nd }}$ were using paddle apparatus with 75 RPM rotation, temperature $37{ }^{\circ} \mathrm{C}$, and dissolution time for 30 minutes.

\subsubsection{System Suitability Test}

System suitability test was done by injected standard solution for assay and dissolution test for 6 times and the HPLC results were evaluated against the RSD area value, retention time, resolution, the number of theoretical plates, tailing factor, and the capacity factor.

\subsubsection{Solution Stability Test}

The stability test of the solution was carried out by injecting a standard solution and 
simulation sample for assay and dissolution test at a time range of $0,3,6,8$, and 24 hours, with 3 replication. The analysis results are calculated based on the \% deviation value of the standard solution and the simulation sample between the conditions of the time span to the initial conditions.

\subsubsection{Method Validation}

Specificity: the specificity of assay and dissolution test were made of placebo, reference standard, and simulation sample solution. Then several treatments were carried out such as being heated at $105{ }^{\circ} \mathrm{C}$ for 24 hours, acidified with $1.0 \mathrm{~N} \mathrm{HCl}$ to $\mathrm{pH} 2.0$ for 24 hours, alkalized with $1.0 \mathrm{~N} \mathrm{NaOH}$ to $\mathrm{pH} 12$ for 24 hours, added $10 \% \mathrm{H}_{2} \mathrm{O}_{2}$ for 24 hours, and exposed to $254 \mathrm{~nm}$ UV light for 1 hour. Then the results of the peak chromatogram of the analyte from various treatment conditions were observed.

Linearity: the linearity of assay and dissolution test were made 7 series concentration of Ursodeoxycholic acid standard solution $(50,70,80,90,100,110$, and $130 \%$ ) and then made a linear regression curve. The acceptance criteria for linearity is correlation coefficient value must be $\geq 0.999$.

Accuracy: the accuracy of assay and dissolution test were carried out on the simulation sample and standard solution in the concentration range of $80,100,120 \%$ and each concentration was made 3 replication. Then the percentage recovery of Ursodeoxycholic acid was calculated. Accuracy parameter are accepted if percentage recovery values of these three concentration are within the range $98-102 \%$ with RSD $<2 \%$ for assay ${ }^{16}$ and 95 $105 \%$ with RSD $<5 \%$ for dissolution test. ${ }^{17}$
Precision: the repeatability and intermediate precision of assay and dissolution test were carried out on the simulation sample solution and $100 \%$ concentration of standard solution which made 6 times. Then the level obtained of Ursodeoxycholic acid was determined. Precision criteria are accepted if $\mathrm{RSD}$ value $<2 \%$ for assay ${ }^{18}$ and $<5 \%$ for dissolution test. ${ }^{19}$

LOD and LOQ: LOD and LOQ of the assay and dissolution test were calculated from the linearity curve used the following equation:

LOD $=3,3 \mathrm{x} \frac{S_{y / x}}{b} ; \mathrm{LOQ}=10 \mathrm{x} \frac{S_{y / x}}{b}$ with $S_{y / x}=\left[\frac{\Sigma\left(y i-y i^{\prime}\right)^{2}}{n-2}\right]^{1 / 2}$

\subsubsection{Application of Developed Method}

Samples of Ursodeoxycholic acid capsules $250 \mathrm{mg}$ was prepared for assay and dissolution test. Furthermore, the amount of Ursodeoxycholic acid in the tested sample was calculated using a validated analytical method.

\section{Results}

3.1. System Suitability Test

System suitability test results at Table 1 show that all parameters evaluated fit into the acceptance criteria for System Suitability Test according to USP $42^{\text {nd }}$ editon and chromatogram profile show in Figure 2.

\subsection{Solution Stability Test}

From the results solution stability of the assay and dissolution test, the reference standard and the simulation sample solution are still stable for 24 hours because their produced a $\%$ deviation value $<2 \%$ to the initial conditions.

Tabel 1. System Suitability Test

\begin{tabular}{cccc}
\hline Parameters & Assay & Dissolution Test & Acceptance Criteria (USP \\
\hline TR (minute) & 5.428 & 5.433 & \\
RSD area (\%) & 0.319 & 0.261 & $<2 \%$ \\
N & 5382.480 & 6172.011 & $>2000$ \\
Tf & 1.592 & 1.611 & $<1.7$ \\
k' & 26.123 & 26.166 & $>2$ \\
Rs & 6.813 & 2.087 & $>1.5$ \\
\hline
\end{tabular}


Tabel 2. Specificity

\begin{tabular}{ccccccc}
\hline & \multicolumn{3}{c}{ Assay } & \multicolumn{3}{c}{ Dissolution Test } \\
\hline Condition & $\begin{array}{c}\mathbf{T}_{\mathrm{R}} \text { UDCA } \\
\text { in standard }\end{array}$ & $\begin{array}{c}\mathbf{T}_{\mathrm{R}} \\
\text { UDCA in } \\
\text { simulation }\end{array}$ & $\begin{array}{c}\mathbf{T}_{\mathrm{R}} \text { UDCA } \\
\text { in placebo }\end{array}$ & $\begin{array}{c}\mathbf{T}_{\mathrm{R}} \text { UDCA } \\
\text { in standard }\end{array}$ & $\begin{array}{c}\mathbf{T}_{\mathrm{R}} \text { UDCA in } \\
\text { simulation }\end{array}$ & $\begin{array}{c}\mathbf{T}_{\mathrm{R}} \text { UDCA } \\
\text { in placebo }\end{array}$ \\
\hline Normal & 5.375 & 5.373 & - & 5.611 & 5.614 & - \\
Thermal degradation & 5.349 & 5.346 & - & 5.604 & 5.604 & - \\
Alkali degradation & 5.336 & 5.345 & - & 5.368 & 5.331 & - \\
Acid degradation & 5.367 & 5.366 & - & 5.614 & 5.618 & - \\
Peroxide degradation & 5.374 & 5.378 & - & 5.627 & 5.627 & - \\
UV light effect & 5.369 & 5.369 & - & 5.616 & 5.620 & - \\
\hline
\end{tabular}

\subsection{Method Validation}

\section{a. Specificity}

From the results of the specificity test for the assay and dissolution test at Table 2, it can be seen there is no interference from placebo (Figure 1) and peaks of the compound degradation which has the same retention time as Ursodeoxycholic acid peak, therefore this method can capture specific analyte signals for assay and dissolution test.

\section{b. Linearity}

Linearity results for assay was tested with standard Ursodeoxycholic acid in concentration range of 400.060-1040.156 $\mu \mathrm{g} / \mathrm{mL}$ and for dissolution test in range of 125.177-325.230 $\mu \mathrm{g} / \mathrm{mL}$. The calibration curve, linear regression equation, and correlation coefficient value (R) for assay are shown in Figure $2 \mathrm{a}$ and for dissolution test are shown in Figure $2 b$. The results showed good linearity with correlation coefficient value $(\mathrm{R})$ 1 and 0.9995 for assay and dissolution test respectively.

\section{c. Accuracy}

From the results of accuracy at Table 3 , it was obtained that the average value of the percent recovery from three concentration ranges for the assay was $100.018 \pm 0.888 \%$ with RSD value of $0.887 \%$. While the average value of the percent recovery from three concentration ranges for dissolution test was $98.936 \pm 2.214 \%$ with $\mathrm{RSD}$ value of $2.146 \%$.

d. Precision

Precision results for assay and dissolution test are shown at Table 4. The

Tabel 3. Accuracy

\begin{tabular}{cccc}
\hline \multirow{2}{*}{ Level } & Sample No. & Assay & Dissolution Test \\
\cline { 2 - 4 } & 1 & Recovery (\%) & Recovery (\%) \\
\hline \multirow{2}{*}{$80 \%$} & 2 & 101.184 & 95.992 \\
& 3 & 100.815 & 98.418 \\
& 1 & 100.700 & 96.406 \\
$100 \%$ & 2 & 100.534 & 98.839 \\
& 3 & 100.294 & 97.453 \\
& 1 & 99.789 & 99.210 \\
$120 \%$ & 2 & 98.901 & 101.447 \\
& 3 & 99.081 & 100.750 \\
\hline Average RSD & & 98.869 & 101.913 \\
\hline
\end{tabular}



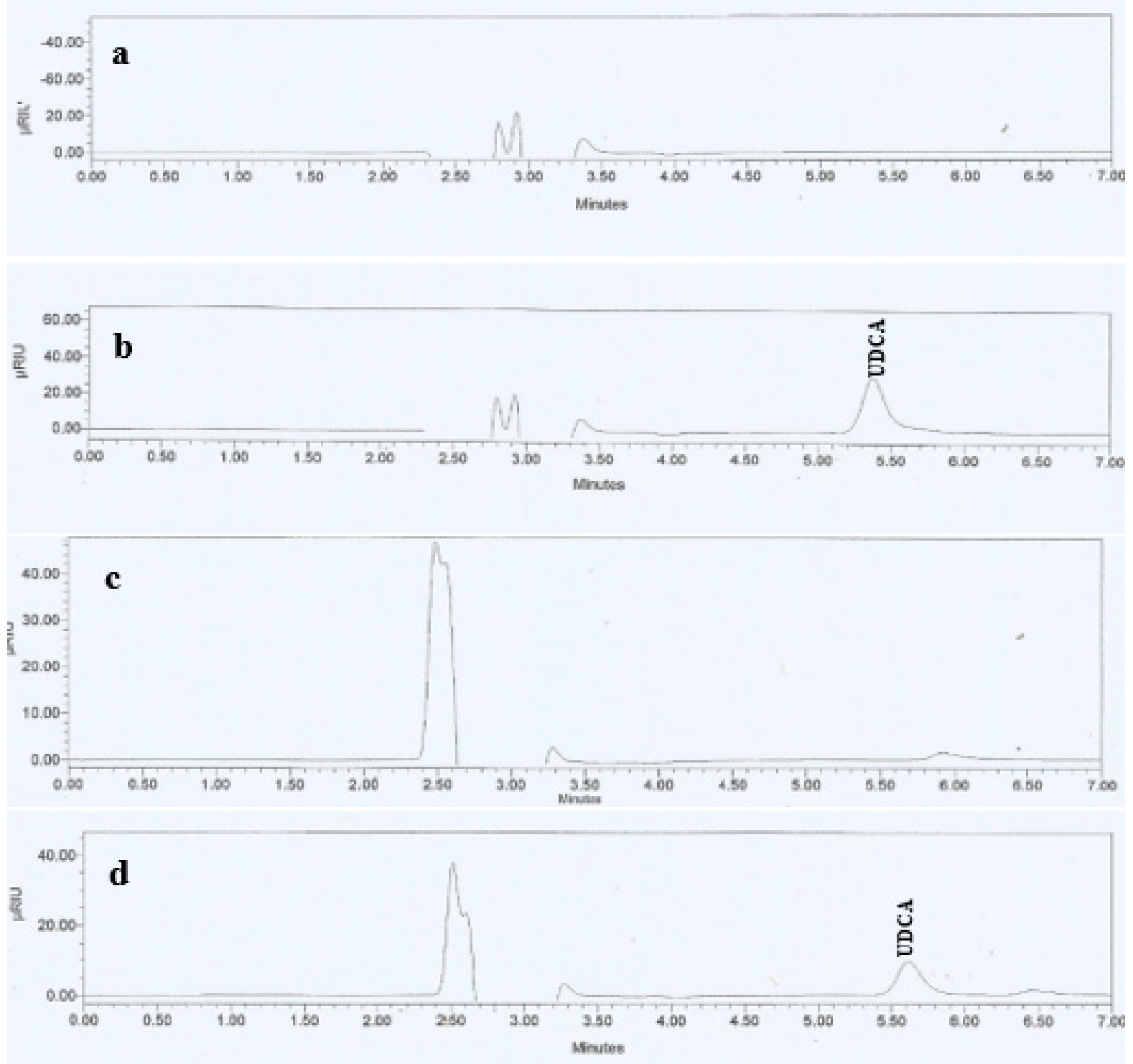

Figure 1. Chromatogram specificity of Ursodeoxycholic acid between placebo solution (a) and simulated sample solution (b) for assay; placebo solution (c) and simulated sample solution (d) for dissolution test

repeatability for assay was obtained the RSD value of $0.466 \%$ while the intermediate precision obtained the RSD value of 0.279 $0.483 \%$. From the repeatability for dissolution test was obtained the RSD value of $1.16 \%$ while the intermediate precision obtained RSD value of $0.032-0.289 \%$.

\section{e. LOD and LOQ}

LOD and LOQ were calculated from the linear regression equation. LOD and LOQ for assay were $4.892 \mu \mathrm{g} / \mathrm{mL}$ and $14.824 \mu \mathrm{g} /$ $\mathrm{mL}$ respectively. Whereas for the dissolution test, LOD and LOQ were $6.501 \mu \mathrm{g} / \mathrm{mL}$ and $19.701 \mu \mathrm{g} / \mathrm{mL}$ respectively.

\subsection{Application of Developed Method}

From the assay result of the Ursodeoxycholic acid capsule product, the average percent concentration obtained from 6 capsules was $103.50 \pm 1.47 \%$ and the dissolved Ursodeoxycholic acid was $97.61 \pm 3.97 \%$.

\section{Discussion}

In this research, the analytical method has been successfully developed for Ursodeoxycholic acid capsules using the HPLC-RID and the mobile phase mixture of acetonitrile:0.075 phosphate buffer $\mathrm{pH} 3.0$ $(55: 45 \mathrm{v} / \mathrm{v})$, so it can be used to analyze of assay and dissolution test simultaneously with 
Tabel 4. Precision

\begin{tabular}{|c|c|c|c|c|c|c|}
\hline \multirow{4}{*}{ No } & \multicolumn{3}{|c|}{ Assay } & \multicolumn{3}{|c|}{ Dissolution Test } \\
\hline & \multirow{2}{*}{ Repeatability } & \multicolumn{2}{|c|}{ Intermediate Precision } & \multirow{2}{*}{ Repeatability } & \multicolumn{2}{|c|}{ Intermediate Precision } \\
\hline & & Analyst 1 & Analyst 2 & & Analyst 1 & Analyst 2 \\
\hline & \multicolumn{3}{|c|}{ Content Obtained (mg) } & \multicolumn{3}{|c|}{ Content Obtainrd (mg) } \\
\hline 1 & 201.035 & 200.844 & 197.589 & 247.570 & 246.434 & 244.399 \\
\hline 2 & 202.827 & 202.641 & 196.804 & 244.116 & 242.366 & 245.991 \\
\hline 3 & 200.075 & 200.761 & 197.343 & 248.667 & 246.922 & 245.997 \\
\hline 4 & 201.016 & 199.678 & 197.202 & 246.412 & 248.195 & 245.539 \\
\hline 5 & 201.347 & 201.450 & 198.443 & 246.978 & 248.690 & 245.108 \\
\hline 6 & 200.552 & 200.925 & 197.643 & 252.566 & 251.492 & 244.497 \\
\hline Average & 201.142 & 201.050 & 197.504 & 247.718 & 247.350 & 245.255 \\
\hline SD & 0.938 & 0.971 & 0.550 & 2.816 & 0.080 & 0.708 \\
\hline RSD & 0.466 & 0.483 & 0.279 & 1.137 & 0.032 & 0.289 \\
\hline
\end{tabular}

*UDCA was added for assay : $200 \mathrm{mg}$; UDCA was added for dissolution test: $250 \mathrm{mg}$

the same chromatographic conditions system. The dissolution test of Ursodeoxycholic acid capsules was carried out in phosphate buffer $\mathrm{pH} 8.4$ because at $\mathrm{pH}<7$ Ursodeoxycholic acid showed polymorphic transformation into water-insoluble crystals. ${ }^{20}$ SLS was added to medium to increase the dissolution of poorly water soluble acidic drugs such as Ursodeoxycholic acid. ${ }^{21}$

System suitability test (SST) was done and used to ensure that the complete analytical system including reagents, instrument, column, and analyst are suitable for intended application..$^{22}$ From the parameter results were evaluated in SST it can be concluded that analytical systems are ready to do analysis.

Solution stability test is important as a stage of prevalidation in order to estimate the time between preparation all solutions and the time when the analysis is started. From the results of solution stability test, Ursodeoxycholic acid reference standard and sample solution are stable for 24 hours in each solvent.

To assess the performance of this development method, validation parameters such as specificity, linearity, accuracy, precision, LOD and LOQ were evaluated. The validation results show that this method is specific to the analyte for assay and dissolution test because there is no interference from the compound degradation and placebo at the peak of analyte. This result is in accordance with previous research that Ursodeoxycholic acid does not degraded when thermal, acid, alkaline, peroxide degradation, and exposed to UV light were carried out. ${ }^{23}$

The linearity results obtained the correlation coefficient $(\mathrm{R})$ for the assay and dissolution test of 1 and 0.9995 , respectively. The linearity results in this study show in a fairly good $\mathrm{R}$ value than previous studies for assay that resulted (R) $0.9951^{24}$, and (R) $0.9998^{25}$. Whereas for the dissolution test from previous study the $(\mathrm{R})$ value was $(\mathrm{R})$ $0.9990 .{ }^{26}$

The average percent recovery for assay in this study were obtained at $100.018 \pm 0.888$ with RSD value of $0.887 \%$ and for dissolution test of $98.936 \pm 2.124$ with RSD value of $2.146 \%$. Based on previous research, it was found the percent recovery value for assay was $99.573 \%$ with RSD value of $0.485 \% .{ }^{27}$ Whereas in previous studies for the dissolution test by Sawant and Mane, the percent recovery value was $99.6 \%$ with RSD value of $0.38 \%$. Therefore, in this study RSD value for assay was smaller than the previous research, but for the dissolution test was still greater than previous studies.

The results of repeatability and intermediate precision for assay the RSD values were $0.466 \%$ and $0.279-0.483 \%$, respectively. From the previous research by 

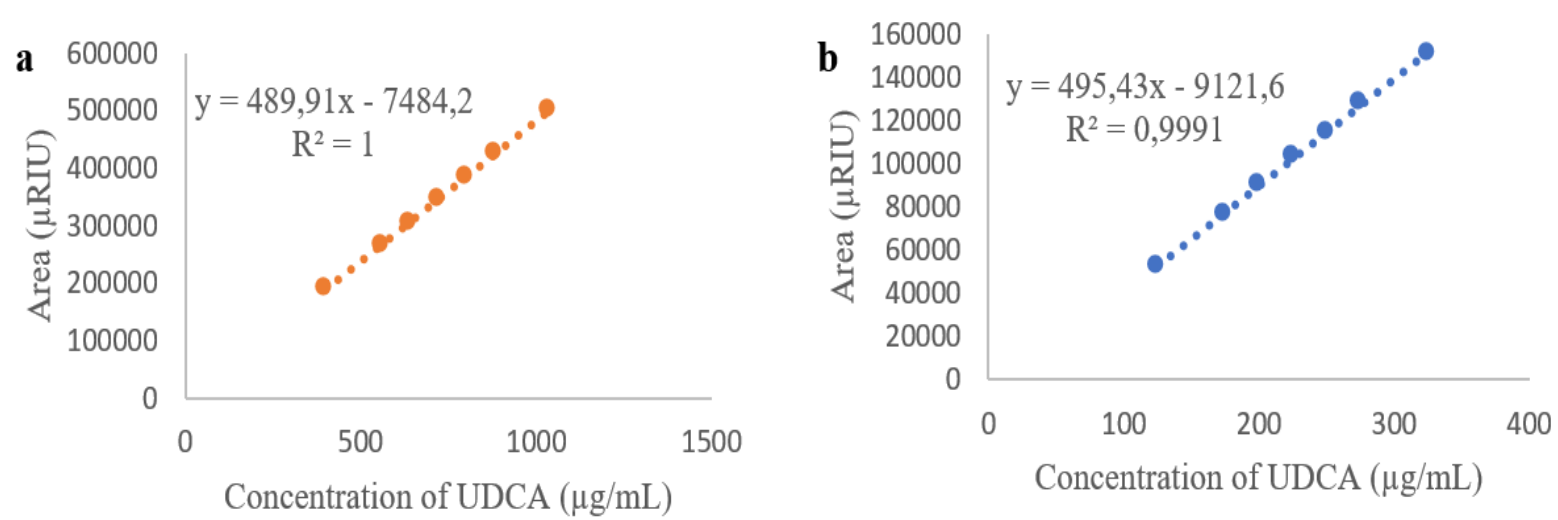

Figure 2. Calibration curve of Ursodeoxycholic acid for assay (a) and dissolution test (b)

Varinder et al., it was found the RSD value for assay was $1.94 \%$ and the intermediate precision was $1.84 \%$ therefore, this method produced a smaller RSD value compared to previous studies. Based on the repeatability and intermediate precision for dissolution test in the previous study by Sawant and Mane, the RSD values were $1.6 \%$ and $1.5 \%$ respectively. Therefore, in this study the RSD values were smaller than the previous dissolution validation studies.

The LOD and LOQ values obtained for assay were $4.892 \mu \mathrm{g} / \mathrm{mL}$ and $14.824 \mu \mathrm{g} /$ $\mathrm{mL}$, while the dissolution test were $6.501 \mu \mathrm{g} /$ $\mathrm{mL}$ and $19.701 \mu \mathrm{g} / \mathrm{mL}$ respectively. While the LOD and LOQ values for assay in the previous study by El-Kafrawy et al were $8.19 \mu \mathrm{g} / \mathrm{mL}$ and $27.27 \mu \mathrm{g} / \mathrm{mL}$. Therefore, the sensitivity of this method is higher than the previous research. Meanwhile, the dissolution validation test in the previous study did not calculate LOD and LOQ. From the LOD and LOQ values in present study, this method still satisfy for quantification of Ursodeoxycholic acid in formulation because from previous research the usual concentration of Ursodoxycholic acid from sample formulation in the test solution in between 200-15000 $\mu \mathrm{g} / \mathrm{mL}$. 7,9,10,11,14,23,24,25,26,27

From the results assay of Ursodeoxycholic acid capsule samples, it was obtained the average concentration of 6 capsules was $103.50 \pm 1.47 \%$ and Ursodeoxycholic acid dissolved was $97.61 \pm 3.97 \%$. This value meets the requirements set by the USP $42^{\text {nd }}$ for assay between $90-110 \%$ and dissolution test $\geq 80 \%$ for Ursodeoxycholic acid capsule.

\section{Conclusions}

The results validation of the analytical method showed the method development in this study are linear, selective, accurate, and precise so it can be used simultaneously for the assay and dissolution test of Ursodeoxycholic acid capsule with the same chromatographic condition systems.

\section{Acknowledgement}

The authors would like to thank PT. Kimia Farma Plant Banjaran, Bandung, Indonesia for providing the facilities to carried out this research.

\section{References}

1. Wan JF, Chu SF, Zhou X, Li YT, He WB, Tan F, et al. Ursodeoxycholic acid protects interstitial Cajal-like cells in the gallbladder from undergoing apoptosis by inhibiting TNF- $\alpha$ expression. Acta Pharmacol Sin. 2018;39(9):1493-500.

2. Hopf C, Grieshaber R, Hartmann $\mathrm{H}$, Hinrichsen $\mathrm{H}$, Eisold $\mathrm{M}$, Cordes $\mathrm{HJ}$, et al. Therapeutic equivalence of ursodeoxycholic acid tablets and ursodeoxycholic acid capsules for the treatment of primary biliary cirrhosis. Clin Pharmacol Drug Dev. 2013;2(3):231-6.

3. Pavlović N, Goločorbin-Kon S, Danić M, Stanimirov B, Al-Salami H, Stankov $\mathrm{K}$, et al. Bile acids and their derivatives as potential modifiers of drug release and pharmacokinetic profiles. Front Pharmacol. 2018;9(11):1-23. 
4. Telange DR, Denge RP, Patil AT, Umekar MJ, Gupta SV, Dave VS. Pentaerythritol as an excipient/solid-dispersion carrier for improved solubility and permeability of ursodeoxycholic acid. J Excipients Food Chem. 2018;9(3):80-95.

5. Desai MS, Penny DJ. Bile acids induce arrhythmias: Old metabolite, new tricks. Br Med J. 2013;99(22):1629-30.

6. Raini M, Mutiatikum D, Lastari P. Dissolution profile and determination of loratadine content in innovator and branded generic tablet. Media Litbang Kesehatan. 2010;20(2):59-64.

7. El-Kafrawy DS, Belal TS, Mahrous MS, Abdel-Khalek MM, Abo-Gharam AH. Validated spectrophotometric and RP-HPLC-DAD methods for the determination of ursodeoxycholic acid based on derivatization with 2-nitrophenylhydrazine. J AOAC Int. 2017;100(3):677-85.

8. Patil SJ, Kane SR, Mohite SK, Magdum CS. Development and validation of UV spectrophotometric method for estimation of Ursodeoxycholic acid in bulk formulation. Asian J Pharm Anaysis. 2020;10(3):155-7.

9. Hasan N, Chaiharn M, Abbas T, Sherwani SK, Mukayeva S, Shah SN, et al. Development and validation of RP-LC-UV method for determination of ursodeoxycholic acid in capsule and human serum. World Appl Sci J. 2014;32(4):560-6.

10. Sawant TB, Mane DV. Chromatographic method development and validation for quantitative determination of ursodeoxycholic acid in ursodeoxycholic acid tablets. Asian J Chem. 2018;30(10):2373-6.

11. Singh S, Saini M, Kumar A, Manral K, Joshi S. Method development and validation for estimation of ursodeoxycholic acid in tablet dosage form by HPLC. 2020;3(3):14-23.

12. Peepliwal A, Bonde CG, Bothara KG. A validated RP-HPLC method for quantitative determination of related impurities of ursodeoxycholic acid (API) by refractive index detection. J Pharm Biomed Anal. 2011;54(4):845-9.

13. Roda A, Gatti R, Cavrini V, Cerrè C, Simoni P. HPLC study of the impurities present in different ursodeoxycholic acid preparations: Comparative evaluation of four detectors. J Pharm Biomed Anal. 1993;11(8):751-60.

14. Mukherjee J, Pal TK. Development and validation of RP-HPLC method to determine ursodeoxycholic acid in pharmaceutical dosage forms. Int J Pharm Sci Res. 2011;2(1):73-8.

15. Jafer Vali S, Kumar SS. Separation and Quantification of Octahydro-1h-Indole-2Carboxilic Acid and Its Three Isomers by HPLC using Refractive Index Detector. J Chromatogr Sep Tech. 2012;03(04):2-7.

16. Madhu M, Satyadev TNVSS, Hephzibah G, Reddy TV. Validated RP-HPLC method for the determination of estradiol valerate in bulk and pharmaceutical formulations. Der Pharm Lett. 2016;8(4):50-61.

17. Kulkarni AP, Shahnawaz M, Zaheer Z, Dehghan MHG. Development and validation of a dissolution method for pioglitazone tablets. Dissolution Technol. 2012;19(4):36-45.

18. Nugrahani I, Dillen N. Rapid assay development of diclofenac sodium coated tablet assay using FTIR compared to HPLC method. Int J Appl Pharm. 2018;10(4):43-50.

19. Vaghela BJ, Kayastha R, Bhatt N, Pathak N, Rathod D. Development and validation of dissolution procedures. J Appl Pharm Sci. 2011;1(3):50-6.

20. Horkovics-Kovats S, Ulč I, Vít L, Němec B, Rada V. Physicochemical pharmacokinetics as an optimization tool for generic development: A case study. Eur J Pharm Sci. 2018;111(17):349-57.

21. Haroon U, Zuberi MH, Razi S. The effect of $\mathrm{pH}$ and surfactant on the dissolution profile of poorly water soluble drug and it ' $s$ in vivo implications. Pelagia Res Libr. 2018;9(2):662-6.

22. Tontala F. Automate System Suitability Testing with Chromatography Software. Thermo Fisher Scientific Technical Note 
708. 2014.

23. Kumar A. Development and validation of RP-LC-UV method for determination of ursodeoxycholic acid in drug subtance and drug product. J Glob Trends Pharm Sci. 2014;5(1):1399-404.

24. Boscolo O, Flor S, Dobrecky C, Salvo L, Tripodi V, Lucangioli S. Development and validation of a LC-UV method applied to the quality control of ursodeoxycholic acid in raw material and pharmaceutical pormulations. IOSR J Pharm. 2017;07(02):111-6.

25. Kanth ML, Kamal RB. Analytical method development and validation for the estimation of ursodiol in bulk and pharmaceutical formulation by RP-HPLC. Int J Pharm Anal Res. 2018;7(3):278-84.

26. Sawant TB, Mane DV. Dissolution method development with chromatographic method for determination of drug release in dissolution samples of ursodeoxycholic acid tablets. J Drug Deliv Ther. 2018;8(1):23-8.

27. Varinder S, Kumar P, Gurjeet S, Shah G, Dhawan RK. Analytical method development and validation for the estimation of pioglitazone hydrochloride by using RP-HPLC. Int $\mathrm{J}$ Sci Technol Res. 2015;8(10):3567-78.

28. International Conference on Harmonisation. Text and Methodology. Vol. Q2. Canada: ICH Harmonised Tripartite Guideline; 2005. Validation of Analytical Procedures; p. 1-13.

29. The United States Pharmacopeia. National Formulary 37. Vol. 42. Rockville (MD): United States Pharmacopeial Convention; 2019. Ursodiol Capsules; p. 4518. 